\title{
NUWE ONTWIKKELINGE OP DIE GEBIED VAN DIE KATEGESE
}

\section{Dr. M. A. Kruger}

IN wat hier aan $u$ gebied word, sal ek nie vernuwing op die gebied van die kategese in besonderhede gaan sien nie, maar oor vernuwing in die algemeen iets probeer sê. Dit is die taak van ander referente om te wys op vernuwing in bepaalde kategismusse, op bepaalde gebiede of ook wel die leemtes of vrae op bepaalde gebiede. Hier is dit my taak om oor al die vernuwing koördinerend te probeer handel, om samevattend weer te gee wat op soveel verskillende plekke en op die verskillende terreine van die kategese gedoen word en les bes om te probeer om aan te toon waar vernuwing nog behoort te kom of bestaande vernuwing nie as waardevol beskou kan word nie.

Die volgende sal behandel word:

1. die belangrikheid van vernuwing in kategese;

2. is daar reeds vernuwing?;

3. vernuwing t.o.v. die wese en doel van die kategese;

4. vernuwing t.o.v. die objek van kategese;

5. vernuwing t.o.v. die subjek van kategese;

6. vernuwing t.o.v. die metode in kategese;

7. vernuwing t.o.v. die leerstof in kategese;

\section{Die belangrikheid van vernuwing}

Stemme wat die belangrikheid van kategese beklemtoon, klink reeds vir 'n geruime tyd op uit die lande waar die Christelike Kerk nog jonk is en waar kerk en sending nog dikwels ' $n$ ineengestrengelde taak het. Die belangrikheid van goeie kategese word deur sowel die Protestantse wêreld as die Rooms Katolieke wêreld erken. In Afrika kan slegs geluister word na die woorde van Botha wat grondige kategese as 'n bolwerk teen sinkretisme sien, ${ }^{1}$ terwyl Luzbetak dit vir Suid-Amerika reeds eerder beklemtoon het ${ }^{2}$ en daar ook dieselfde stem uit Asië opgaan. ${ }^{3}$

Terwyl die Christelike wêreld steeds meer wegkom van die gedagte dat sending net bedoel is vir verre lande, vir die Derde Wêreld, en die waarheid van die uitdrukking Sending in Ses Kontinente altyd skerper raakgesien word, word die noodsaaklikheid van deeglike kategese egter ook besef in lande soos Frankryk en ander en word daar nuwe aspekte onder die kategetiese soeklig gestel.4

In Afrika het die Christelike godsdiens so snel posgevat dat daar wel vooruit bespiegel kan word dat dit die kontinent sal wees waar die Christelike Kerk miskien in die komende eeu die sterkste sal vertoon. ${ }^{3}$ Tog word oor die feit dat juis in Afrika die Christelike godsdiens nog nie diep wortel geskiet het nie, uit verskeie oorde gepraat. ${ }^{6}$

Daar word ronduit gesê dat daar soms oorhaastig gedoop is op 
die sendingveld sonder behoorlike onderrig7 en net so word ook met reg beweer dat valse motiewe dikwels gegeld het om tot die Christelike godsdiens toe te tree. ${ }^{8}$ Dis miskien in die lig hiervan dat daar ook van Rooms-Katolieke kant gestel word dat die groot taak in Afrika vandag vir hulle is om te konsolideer in die kerk en nie om in die eerste instansie deur sending nuwelinge te betrek nie. ${ }^{9}$

Omdat kategese inderdaad Woordverkondiging is, ${ }^{10}$ word dit ook genoem die hart van die gemeente, ${ }^{11}$ hartaar van die Kerk ${ }^{12}$ en word vanuit die Bybel opnuut besin oor die taak van kategese. ${ }^{13}$

Hoewel daar 'n algemene bewuswording van die waarde van kategese is, ${ }^{14}$ word die noodsaaklikheid van vernuwing tog nog sterk beklemtoon as iemand soos Pierce skryf oor die traagheid om te verander. ${ }^{15}$

Wanneer ons terugkyk op die geskiedenis sedert die eerste eeu, bemerk ' $n$ mens dat daar sekere tye van stroomversnellings gekom het in die vloei van die groot stroom van die geskiedenis. Laat ons slegs die erkenning van die Christelike godsdiens deur die staat, die Renaissance en die Reformasie noem. Vandag leef ons weer midde in ' $n$ stroomversnelling - miskien moet ' $n$ mens eerder van 'n waterval praat. Omdat ons daarbinne staan en nie weet of die water nog maar begin stort oor die rand van die rots en of dit al geval het tot naby die vlak waar dit weer gelyker gaan vloei nie, word die belangrikheid daarvan dat die kinders van die Here gereedgemaak sal word om hierdie tyd te aanvaar met roepingsbewustheid net sterker aan ons opgedring. Uit verskeie windrigtings word dan ook die waarde van die kategese vir die eie tyd beklem. toon. ${ }^{16}$

\section{Is daar reeds vernuwing?}

Dat daar 'n wêreldwye vernuwing op die gebied van kategese is, is duidelik as 'n mens lees van 'n kategetiese beweging, ${ }^{17}$ 'n geweldige oplewing in die belangstelling vir kategese, 18 'n nuwe bedeling wat betree word, 19 ' $n$ wêreldwye besinning ${ }^{20}$ en daar van Asië al selfs 'n geskiedenis van die moderne vernuwing in die kategese geskryf word. ${ }^{21}$

Terwyl die sending ook begin dink om in 'n ander vorm aanwesig te wees as in die verlede in Afrika en Asië ${ }^{22}$ word ook die kategese ten nouste by hierdie vernuwing betrek.

In die jongse geskrifte oor kategese klink die geluide van die moderne teologie ook al duideliker op. Prins sê: „Wanneer ons nou let op die kategese soos dit in hierdie nuwe benadering beoefen word, kan ons ook nie anders as om die ,stemme van die moderne tyd' te verneem, in plaas van die getuienis van die Skrif nie".23 Hoewel dit juis merkwaardig is hoe algemeen sowel die RoomsKatolieke as die Protestantse besinning oor kategese die Bybel in die sentrum wil stel - waaroor later meer - is hierdie waarskuwing van Prins nie sonder rede nie en kan daar nie maar vernuwe word sonder om hierdie vernuwing ook teen die agtergrond van die moderne teologie te beoordeel nie. In hierdie verband wil ek slegs 
enkele aspekte van die vernuwing noem.

Die ander siening van die saligheid van die mens wat algemeen deur die nuwere teologie gebring word, vind ook weerklank in die kategese. Hiervolgens moet die saligheid nie as iets los van hierdie lewe, 'n belewenis vir die lewe hierna, gesien word nie, maar moet die huidige lewe as basis vir die saligheid gesien word, soos Rahner en Congar dit o.a. stel. ${ }^{24}$ Maar dit is nou reeds algemene kennis hoedat hierdie waarheid dat die saligheid van die toekomstige volkome lewe saamhang met die genade wat reeds in hierdie lewe ervaar word, verwring word tot 'n soeke van die saligheid net in hierdic lewe. ${ }^{25}$

Wanneer Pierce skryf oor die "Life theme"-metode in die kategese $^{26}$ hoor 'n mens duidelik dieselfde noot as in die rapport van die Wêreldraad van Kerke, ,The Church for Others" wat stel dat die sending in die verlede miskien die taak gehad het om te vra na die ware God en die mens na Hom te lei, maar tans die taak het om te vra na die ware mens. ${ }^{n}$ Hierdie horisontalisme spreek ook duidelik uit die slagspreuke wat Bucher vir die jeug stel..$^{28}$

Behalwe hierdie intrekking van die verlossingswerk tot iets vir hierdie aarde en vir hierdie tyd en die mens wat so in die sentrum gestel word, word ook in die nuwe besinning oor kategese 'n opvatting uit die nuwere teologie oor wat openbaring is soms aanvaar. Dit kom daarop neer dat 'n voortgaande openbaring van Christus se werksaamhede in die huidige tyd gelykgestel word met die openbaring in die Woord. ${ }^{29}$ Hierin sluit die gedagtes oor die kosmiese betekenis van Christus en die Rooms-Katolieke leer van die natuurlike Godskennis by mekaar aan. So word 'n geheel ander saligmakende werksaamheid van Christus buite die Woord om wat deur die Kerk gebring moet word, aanvaar.

So word ook gesê dat Christus in die kategese te midde van die wêreldgodsdienste as die kulminasiepunt van openbaring gesien moet word. ${ }^{30}$ Dit bring natuurlik 'n oorwaardering van die heidense godsdienste mee wat vir die wêreld van vandag wel aangenaam en maklik is om te aanvaar, maar wat nie strook met die uniekheid van die openbaring in Jesus Christus soos dit deur die Bybel geleer word nie.

Oor die moderne vernuwing kan samevattend gesê word dat in die Kategetiek eintlik nie iets totaal nuuts gebring word nie. Dit is eerder ' $n$ geval van 'n verlegging van klemtone, van verwyding van perspektief en van 'n integrasie van die verskillende terreine van die kategese. Wat die naaste kom aan iets wat wel nuut is, is die bydrae van die moderne teologie. Ten opsigte van laasgenoemde kan sekerlik die positiewe gestel word, maar dat die negatiewe 'n bedreiging is vir 'n Skrifgefundeerde kategese is ewe-eens waar. Hoewel daar dan nie van opspraakwekkende nuwe dinge gespreek kan word nie, is die vernuwing daarom nie van minder belang nie, maar m.i. van die allergrootste waarde juis omdat ons in so ' $n$ besondere tyd leef en die gelowige in alle opsigte gereed gemaak moet word om sy taak in hierdie wêreld met kundigheid, moed en vertroue te aanvaar. 


\section{Vernuwing t.o.v. die wese en doel van kategese}

Uit die Nuwe Testament kan ons vasstel dat die woord $\kappa \alpha \tau \eta \chi \varepsilon \omega$ beteken om van iets te vertel of in die passief dat berig ontvang word van iets. Verder kan ons uit die geskrifte van Paulus aflei dat hy dit uitsluitlik gebruik met die betekenis dat onderrig aangaande die geloof gegee word. ${ }^{31}$ Hiervolgens kan dit wees dat die woord kategese gebruik kan word vir die onderrig van enige persoon, bondeling of iemand wat nie in die verbond is nie, gelowige of ongelowige..$^{32}$

Die begrip kategese is egter nie net bepaal deur sy Nuwe Testamentiese betekenis nie, maar deur die opvatting wat daarvan histories in die Kerk ontstaan het. Deur hierdie gebruik is die betekenis van onderrig aan ongelowiges nie meer gedek deur die woord nie. Daardie onderrig is gedek deur die woorde wat verband hou met verkondiging en proklamering. Kategese is egter gebruik vir die heiden wat reeds tot bekering gekom het en nou onderrig word met die oog op die Doop en verder vir die onderrig van hulle wat reeds in die verbond is om hulle tot geestelike volwassenheid te bring.

Daar was nooit 'n skerp onderskeid tussen prediking en kategese nie. Dit is ook onmoontlik om dit skerp te skei. ${ }^{33}$ As voorbeeld kan slegs genoem word die gebruik van wat genoem word Kategismus-prediking in die gereformeerde kerke.

Die inhoud van die begrip van kategese is in die geskiedenis meer bepaal vanuit die standpunt van die persoon wat die bepaling gedoen het. Indien 'n persoon se arbeid hoofsaaklik gerig was op die ou bestaande kerk, sy belangstelling in sy geskrif bepaal is deur hierdie kerk en hy weinig met die sending te doen gehad het, is selfs dikwels die definisie van kategese so vereng dat nie eers die kategumenaat van heidense bekeerlinge binne die gesigsveld gekom het nie..$^{34}$ Hierdie groep wat uit die heidene kom, is nie prinsipieel afgewys nie, maar hulle het net eenvoudig nie binne die aandagskring gekom nie.

In die ouer kerke het hierdie gebruik nog tot betreklik onlangs bly voortbestaan. Die beste voorbeeld hiervan is die definisie wat De Villiers gee.35 Vyftien jaar later gee hy egter 'n definisie wat veel ruimer is..$^{36}$ Uit sy eerste definisie kan afgelei word dat hy kategese wou beperk tot slegs die arbeid van die kerk aan sy gedooptes, maar dit is slegs 'n gevoel van wat toe eintlik binne sy gesigsveld was. Uit die tweede omskrywing blyk die uitwerking van die vernuwing wat tans aan die gang is, waar oor die hele wêreld aan die toerusting tot volle geloofsaktiwiteit van alle Christene gedink word.

In die voorbeelde hierbo het ek my beperk tot die siening in die Hollandsgereformeerde tradisie. Wanneer ons buite hierdie tradisie gaan en veral wanneer ons ook die wye besinning wat in die Rooms-Katolieke Kerk aan die gang is oor kategese raaksien, kom die wydheid van perspektief op kategese nog veel meer opdringend op ons aan. ${ }^{37}$ Hierdie wyer siening het m.i. ontstaan en nodig geword a.g.v. die posisie waarin die Kerk hom vandag bevind. Daar is grootskeepse afval in die ou Christelike lande, daar is die neigings in die moderne teologie wat van binne-uit die Christelike godsdiens krag- 
teloos maak en van sy uniekheid beroof, daar is die toenemende materialisme en 'n gebrek aan tyd vir geestelike verdieping, daar is die vordering van die Sending en die afbraak van die Kerk wat maak dat kerk en sending nie meer ver van mekaar af lê soos dit nog ' $n$ eeu gelede was nie, maar dat hulle geografies altyd bymekaar is. Al minder is dit die geval dat een volk ' $n$ voorwerp van sending en die ander die subjek van sending is. So het dit gekom dat kategese vandag vir almal 'n saak word wat 'n groter verskeidenheid van mense onmiddellik binne sy gesigsveld bring. (Wanneer oor die objek van die kategese gehandel word, sal meer hier omtrent gesê word.)

Omdat die onderrig tot 'n geloofslewe van getuies wees vir Christus in die volle sin van die woord vandag so belangrik is en in die Kerk van vandag elkeen roep om sy deel meer as ooit te bring, word selfs die prediking soms gesubordineer aan die kategese. ${ }^{38}$ Dit mag egter nie so word dat woordbediening kategese is nie, maar kategese is altyd woordbediening.

Terwyl belydenis van geloof en die toegang tot die nagmaal nog altyd eintlik bepalend is vir wat kategese is by sommige, ${ }^{39}$ het ander reeds 'n wyer opvatting waarby hoogstens nog gesê kan word dat in die kategese die leiding tot aflegging van openbare belydenis van geloof en toegang tot die heilige nagmaal effe uitstaan in die reeks spitse van die gesamentlike doel van kategese, maar nie meer dat dit die enigste hoë en verhewe spits is waarby die omliggende toppe eenvoudig uit die gesigsveld verdwyn hoewel hulle tog daar is nie. Wevitavidanelage stel die verandering wat plaasvind of behoort plaas te vind so: „In plaats van een schoolvak, dat goede sijfers kan opleveren bij examens, word de catechese nu steeds meer gezien als een proces van levensvorming, een opvoeding in het geloof, die helpt om de dynamiek en de mystiek van het christendom in het eigen milieu te beleven. De parochie en het gezin gaan langzamerhand de school vervangen als brandpunten van religieuze vorming. Van een catechese die louter was geconcentreerd op het kind wordt het accent geleidelijk verlegd naar de opgroeiende jeugd en volwassenen; van de bezorgdheid om vooral maar veel, informatie' te geven inzake geloof en zeden naar groter zorg voor de ,vorming' van de ,gelovige', die de verantwoording van zijn geloof op zich wil nemen".40

Dit is ook duidelik dat die aksent van kategese verskuif van onderrig in die leer van die kerk na 'n inname van die blye boodskap meer langs die weg van die Bybel as langs die weg van 'n gesistematiseerde kategismus. ${ }^{41}$ Dit het dan ten doel om die geestelike horison van die kategese die volgende te laat insluit: Versigtigheid en openheid, samehang, eenheid en bepaalde swaartepunte, verinnerliking van plig en persoonlike verantwoordelikheid, eerbied vir die misterie en die konkrete, dinamiek van die geloof en 'n positiewe en opbouende karakter. ${ }^{2}$ In die vernuwing t.o.v. die wese en doel van die kategese kom die gedagtes dat kategese moet help tot solidariteit met die wêreld, ${ }^{43}$ dat die Evangelie in die lewe moet staan, $^{4}$ en wat vir my veral mooi gestel is dat God geken en gevrees 
moet word in die Bybelse sin van die woorde, ${ }^{45}$ nou duidelik na vore.

Wat die verandering t.o.v. die wese en doel van die kategese betref, moet ten slotte net nog weer gesê word dat veel wat vroeër verwag is van die prediking alleen nou as taak van die kategese gesien word. Sou dit wees omdat besef is dat die prediking nie werklik tref nie? Kom die prediking nie miskien, veral vir ons gereformeerdes in ' $n$ vakuum waar ons kom luister en loop nie? Hierteenoor het die kategese 'n beter moontlikheid om in die lewe van 'n persoon in te dring. Daar sal m.i. moeilik 'n beter weg opgegaan kan word as wat nou reeds in sekere Gereformeerde en Nederduits Gereformeerde Kerke (om maar net van die twee te praat waarvan ek nou weet) bestaan, $\mathrm{nl}$. dat die bediening van die Woord in die erediens opgevolg word na die erediens met 'n bespreking wat groot kategetiese waarde het.

4. Vernuwing t.o.v. die objek van die kategese

In die voorafgaande afdeling is daar reeds 'n aanduiding dat die objek van die kategese vandag baie ruimer gesien word as tevore. In die verlede het hoofsaaklik net die twee kategorieë van bekeerlinge wat tot belydenis en doop gebring moet word en die verbondskinders as objekte van die kategese in aanmerking gekom. Daar is wel soms gepraat van na-kategese en dit is ook beoefen, maar dan het dit tog nie meer die karakter van eintlike kategese gehad nie. Dit is meer gesien as ' $n$ handeling waar die Kerk besig is met die afloop van 'n saak wat reeds sy hoogtepunt bereik het en wat nie 'n byna net so belangrike doel nog voor het nie.

Die beskrywing van die N.G. Kerk is sy Kerkorde Artikel 42 sien die objek van die kategese soos dit tradisioneel in gereformeerde kerke gesien is:

„... die kinders van die gemeente, asook alle buitekerklikes wat tot die gemeenskap wil toetree..."46 Die neiging is nog by die Afrikaanse kerke in Suid-Afrika om hierdie klem te behou. In niegereformeerde kerke word die objek baie wyer gesien, maar daar is duidelike tekens dat ook in die Afrikaanse kerke aan 'n wyer kring vir die objek aandag gegee word, soos bv. die toenemende belangstelling vir na-kategese duidelik wys. Sterk beklemtoning van die prediking en van veral kategismusprediking bring natuurlik ook mee dat daar nie so maklik nog addisioneel van kategese na aflegging van belydenis van geloof gepraat word nie. By kerke waar laasgenoemde nie bestaan het nie, sal die leemte van kategese natuurlik eerder aangevoel word.

By verskillende skrywers word die kleuter- en kleinkinderfase nou weer sterk beklemtoon. Dit is soms geweldig verwaarloos. Kategese is dikwels wat die verbondskinders betref, vereng tot iets wat eintlik net in die laaste jare voor aflegging van belydenis van geloof geskied. Daar is dan ook met terme gewerk wat hierdie lewensfase van aflegging van belydenis van geloof geweldig in belangrikheid beklemtoon en die vroeëre fase onderbeklemtoon. Die onderskeid vir verbondskinders in Sondagskool en katkisasie waar eersgenoemde die laer ouderdomsgroep is en laasgenoemde die groep wat finaal 
voorberei om hulle geloof openbaar te bely, het nie 'n geringe bydrae gelewer tot verwarring en onderskatting van die belang van die eerste lewensjare nie. ${ }^{47}$ Die bewering dat die belangrikste vormingsjare van die kind $^{48}$ dan hierdie jare is waar finaal voorberei word om belydenis van geloof af te lê, betwyfel ek. My insiens is dit eerder waar dat die kind wat van sy eerste jare af gevorm is, die later jare waar dit moeilik is vir hom om in sy persoonlikheid gebalanseerd te wees goed deurstaan en daarna 'n Christelike koers hou. Die fondament word nie in hierdie jare gelê nie, maar eerder. As die fondament nie gelê is nie, het die kind 'n soveel geringer kans om die storms wat oor almal kom, goed te deurstaan.

Die Joodse gewoonte ${ }^{49}$ en die Bybelse inhoud ${ }^{50}$ leer ons om nie hierdie onderskeid te maak van minder belangrik vir die kleintjies en meer belangrik vir die jare van finale voorbereiding om belydenis van geloof af te lê nie. Die wysheid van God kom juis tot openbaring daarin dat $\mathrm{Hy}$ die opdrag gee om die kinders voortdurend te onderrig en ook as hulle klein is ten volle te ag, omdat Hy langs die organiese weg van die lewe van die verbondskind deur die Heilige Gees sy werk laat doen om die geloof in die kind te wek en te versterk. Dis juis so saam met die lewensgroei van die verbondskind en saam met sy lewe en leer en verkeer in die verbondsgemeente dat die Heilige Gees met die kind geheimnisvol werk soos die wind. Wanneer die kind eendag bewus rekenskap gee aan homself oor die geloof, dan bemerk hy dat dit daar is. In die hele belangrike tyd van sy eerste jare het die Heilige Gees dit in hom bewerk. Daarom mag hierdie lewensfase nie geringgeskat word nie, want die Heilige Gees werk met die Woord wat in die kategese gebring word. Dit stem tot groot dankbaarheid dat daar nou weer skerper belangstelling kom vir hierdie kinderjare sodat tot op die einde van die kleuterstadium veral die plig van die verbondsouer beklemtoon word en vanaf die einde daarvan die plig van die Kerk in amptelike hoedanigheid saam met die ouer. ${ }^{51}$ Bijlsma beklemtoon die belangrikheid van hierdie eerste jare. ${ }^{52}$

Die ouderdomsgroep van die jeug wat belydenis van geloof wil aflê en daarom in die laaste jare van hulle katkisasie voor hierdie groot stap is, ontvang nog altyd orals die nodige aandag in teologiese geskrifte. Dit is net nie meer so alleenuitstaande nie, al is dit nog die belangrikste tyd van die katkisasie, omdat sowel die vorige jare as die daaropvolgende jare nou belangriker geag word en dus meer aandag in beplanning geniet.

Die lidmate van die kerk word deesdae ook na aflegging van belydenis van geloof in groter mate as volwaardige objekte van kategese gesien. Daar is, soos reeds gesê, tevore ook aandag gegee aan na-kategese. Maar na-kategese het altyd die karakter gehad dat daar nog iets gedoen moet word aan 'n taak wat nog nie afgehandel is nie en eintlik al goed afgehandel moes gewees het. Die karakter van volwasse kategese is egter heel anders. Dit gaan uit van die juiste opvatting dat die mens altyd weer opnuut nodig het om onderrig te word om ten volle te leef as gelowige. Aan die een kant is dit so dat die gelowige deur die sonde en die kragtige pogings 
van Satan altyd weer verloor wat hy aan geloofstoerusting gehad het en aan die ander kant is dit so dat elke gelowige deur sy lewe heen moet groei na steeds hoër hoogtes soos die Heilige Gees ons ook altyd verder lei en wil lei na groter heiligheid. Die nuwe beskouing oor die objek van die kategese is nou dat nie net die prediking hierdie laaste taak moet vervul nie, maar ook die werklike kategese daar 'n rol moet vervul. Aflegging van belydenis van geloof is 'n hoogtepunt saam met die voorafgaande kategese, maar dis geen gearriveerdheid nie. Kategete en katkisante moet dit onthou en bepland en doelgerig voortgaan. By die Woordbediening in die huisbesoek en die erediens moet daar ook nog kategese wees om die lidmate toe te rus vir die taak wat hulle in die wêreld van vandag het. By herhaling kan hier net weer verwys word na die metode om groepskategese na die erediens te laat aansluit by die preek wat ook die lidmate wou beweeg om in hierdie wêreld en in hierdie tyd 'n verantwoordelike houding in te neem teenoor God en medemens.

Dit is verblydend dat volwasse kategese oral in die wêreld meer aandag begin geniet.53 Veral in die jong kerke wat nog maar pas uit die sendingstadium is, is dit belangrik. Daar word ook reeds onderskei in leeftydsfases by volwasse kategese om dit meer doeltreffend te maak, ${ }^{54}$ en ook tussen mans en vroue. ${ }^{56}$ Verder is daar ander toespitsings vir besondere groepe bv. vir mense in nywerhede..$^{56}$ Ook wat genoem word familie-kategese word bepleit. ${ }^{57}$

'n Werklik belangrike vernuwing is die aandag wat deesdae aan die verbondskind in die jong kerk gegee word..$^{58}$ Dit was in die verlede so dat die verbondskind in die ouer of sendende kerke kategetiese aandag gekry het en dat die nuwelinge uit die heidendom na hulle bekering dadelik as voorwerpe van kategese gesien is. Maar die verbondskind in die jong kerk, dikwels ook die verbondskind wat saam met die volwasse ouer wat bekeer is, in die kerk gekom het, het nie voldoende of geen kategetiese sorg geniet. Die gebrek aan geloofsaktiwiteit wat daar vandag in die jong kerke gesien word, is tot 'n groot mate die gevolg daarvan.

Wat die voorwerp van kategese betref, moet daar nie eensydig gestel word dat as die kinders nie van kleins af onderrig word, die kerk lam sal wees nie, of aan die ander kant as die ouers nie onderrig word nie, daar nooit lewe sal kom nie, want hulle moet tog die kinders vorm. Albei moet ter hand geneem word. In verhouding tot die tydperk van aflegging van belydenis van geloof word die lewensfase voor en na die tyd vandag meer beklemtoon. Die Kerk sal dus moet wegkom van 'n bietjie peusel aan na-kategese, huwelikskategese, kategese vir doopouers en selfs blote kategismusprediking tot 'n standpunt waar ons alle lidmate ten volle as objekte van kategese bly sien en elkeen volgens sy eie lewensposisie voortdurend katkiseer. Van Afrika sê Hirmer dat kategese eintlik nooit eindig nie. 59

Dit is van die grootste belang dat die objek van die kategese telkens in die verband van die gemeenskap van die heiliges gesien word. 


\section{Vernuwing t.o.v. die sub ek van die kategese}

Die eerste kategeet waarmee die kind in aanraking kom, is sy ouers. In die Ou Testament is die kategetiese funksie van die ouers alreeds sterk beklemtoon. ${ }^{\infty}$ Wêreldwyd word egter gekla dat ouers nie hierdie taak na wense uitvoer nie. Daar is die neiging om dit maar oor te laat aan die amptelike kategese van die kerk. Buehlmann bepleit opleiding van die ouers sodat hulle hul taak beter kan uitvoer.61 Waar huisbesoek gereeld gedoen word, is dit 'n gulde geleentheid om ouers verder in te lig oor die kategese van hulle kinders. Predikante neem soms te maklik aan dat dit 'n eenvoudige taak is wat ouers wel self kan behartig. Die totale onvermoë blyk egter dikwels wanneer die goeie wil daar is om as kategete vir hulle kinders op te tree, maar die ouers nie vir die taak voorberei is nie. Die feit dat 'n mens self gekatiseer het, self die inhoud van die kategese bekom het, is nog lank nie 'n waarborg dat jy ook daardie inhoud kan oordra nie. ' $n$ Belangrike feit is dat die kind wat self by sy ouers gekatkiseer het later self meer bereidheid vertoon om sy eie kinders te katkiseer. Daar moet 'n langtermynbeleid en goeie beplanning gevolg word om ouers individueel en groepsgewys gereed te maak om as kategete vir hulle kinders op te tree. Veral in die jong kerke in Afrika moet hier nog veel gedoen word. Onbekwaamheid en onwil maak dat ouers hierdie taak byna deurgaans nalaat.

Dat die Kerk amptelik besig moet wees met kategese, blyk alreeds uit die voorbeeld van die onderrigtaak wat die priesters volgens die Ou Testament vervul het. As dit nou in die moderne tyd beklemtoon word dat kategese eintlik bediening van die Woord is, dan spreek dit vanself dat die bedienaar van die Woord die eintlike kategeet moet wees. Omdat hy egter onmoontlik altyd die taak alleen kan vervul, is hulpkragte nodig. Dit moet egter steeds so wees dat hiermee nie die taak van die skouers van die bedienaar van die Woord oorgaan op die hulpkragte nie, maar dat die verantwoordelikheid primêr syne bly en dat hy hulle moet lei en voorberei. Dit sal goed wees as die bedienaar van die Woord ten minste die heel klein kinders kan neem en dan weer die belydenisklas. Die gebrek aan goeie hulpkragte maak dit des te meer 'n eis dat die fondament. legging deur die bedienaar self moet geskied. Opleiding van amptelike kategete word bepleit om die gehalte van die kategese te verhoog.62 Meer algemeen word gevra vir beter opleiding van die kragte wat daar is, al is hulle nie uitsluitlik kategete nie. ${ }^{63}$

Daar klink soms 'n toon van moedeloosheid op oor die gehalte van die kategete wat in Afrika moet help. Ons mag egter nie vergeet dat die weg van die Kerk deur die eeue 'n weg was waar die Here met mense wat baie beperkte gawes gehad het tog sy werk gedoen het nie. Weduwees is reeds vroeg gebruik vir die taak van kategese. ${ }^{.4}$ Wanneer die Kerk kategete aanwys, moet hy die heel beste neem, maar wanneer die heel beste maar swak is, moet die Kerk hulle nogtans met vertroue gebruik omdat dit per slot van rekening die Heilige Gees is wat die Groot Leermeester van die Kerk is. Uit verskillende wêrelddele kom ook die klag dat die dag. skole met hulle onderwysers nie meer die ou rol in kategese speel 
nie. ${ }^{65}$ Dit roep juis vir nuwe beplanning t.o.v. hulpkragte. 'n Intellektueel-onontwikkelde kategeet met integriteit en 'n voorbeeld van 'n toegewyde heilige lewe, is veel meer werd as 'n goedgeskoolde kategeet wat hierdie geestelike kwaliteit en liefde nie het nie.

'n Oproep waaraan in die jong kerk in Afrika gehoor gegee moet word, is dat die sendeling hom geleidelik moet onttrek aan die kategese in die Kerk. ${ }^{66}$ Die selfstandige jong Kerk met sy kerkraad moet die verantwoordelikheid aanvaar vir hierdie uiters belangrike taak. As die sendelinge dit voortdurend bly doen, sal dit 'n rem op ontwikkeling tot selfstandigheid en 'n hoër standaard in die kategese wees.

Weens die helder besef wat daar vandag bestaan van die belangrikheid van die eie kultuur en die moeilike taak om vanuit 'n vreemde kultuur jou te kan verplaas in die vel van ' $n$ kultureel totaal verskillende persoon, word allerweë gevra na goeie inheemse kategete. ${ }^{67}$

\section{Vernuwing t.o.v. die metode van die kategese}

Veral wat Afrika betref, is die grootste begeerte tot vernuwing vandag geleë op die vlak van die metode van kategese. 'n Mens kry die indruk dat die aandag tot so 'n mate toegespits word op die metode dat ander noodsaaklike aspekte van die kategese inderdaad verwaarloos word. Verder ontkom 'n mens nie aan die indruk dat by al die gepraat oor die regte metode vir Afrika daar nog weinig positief gedoen word in verband daarmee nie.

Verandering wat voorgestel word t.o.v. die metode het soms selfs invloed op die inhoud van die kategese. Dit is nie net 'n geval van beter of slegter aanbieding van die inhoud na gelang van die metode nie, maar ook van verandering van die inhoud as gevolg van die metode.

Verskillende metodes word nog aan die hand gedoen. In die verlede is die Münchense metode met sy stappe van doel van die les, voorbereiding met 'n storie, verduideliking en toepassing gebruik. Verder is die kerugmatiese metode met as inhoud die blye boodskap, die metode van heilsgeskiedenis en die metode van tematiese onderrig gebruik. Hedendaagse metodes wat gebruik word, is die volgende:

Die bevindelike metode: Die benadering is hier van die kant van die mens en sy situasie. Hierdie metode is deur die RoomsKatolieke Kerk aanvaar te Bangkok in 1962. Die eienaardige is hier dat dit wel kategese genoem word, want die metode is eintlik ontwerp om heidene tot bekering te bring! Kategese is tog vir diegene wat reeds tot bekering gekom het en verbondskinders. As kategetiese metode sal ons dit definitief moet afwys, maar as eerste prediking is daar veel voor te sê en het dit seker groot ooreenkoms met die prediking van Paulus volgens Hand. 17.

Die prosesmetode: Hierdie metode wys uit waar die mensheid vandag ontoereikend is in sy ware mens-wees en lei op die pad van korreksie. Hierdie metode is vir kategese ook onaanvaarbaar omdat 
dit nie standpunt inneem in die openbaring van God nie, maar in die situasie van die mens. Dit moet egter gestel word dat volgens die siening van Pierce wat dié metode noem dit juis standpunt inneem in die openbaring, want hy wil vra hoe en waar openbaar God Hom vandag?

Die lewenstema metode: Hiervolgens word die probleme van die lewe tematies geneem en dan behandel. Ook hierdie metode het geen vaste ankers nie en hoewel dit probeer om van die onsekerheid van die huidige situasie van die mens te kom tot vastigheid sal dit m.i. nie die geval wees nie. In die kategese moet Woordverkondiging voorop gaan. So 'n tematiese behandeling kan ook erg onvolledig en ongesistematiseerd wees wat die geheel van die ken. nis betref wat oorgebring moet word. ${ }^{68}$

Waar hierdie metodes afgewys word, is die diepste rede dat die intensie nie hier duidelik is om met die volle openbaring van God na die mens te gaan nie. Die Bybel word eerder ingeënt (in stukke) op die struktuur van die lewe. Dit moet egter so wees dat terwyl die volle struktuur van die Bybel gegee word die toepassing ook telkens op die lewe gemaak moet word. Hierdie metodes moet dus ingebed wees op die volle openbaring.

Deurgaans word waardering vir die bydrae van die Opvoedkunde en Sielkunde uitgespreek in die geskrifte oor kategese. Dit is niks nuuts nie. Selfs voordat die Opvoedkunde en Sielkunde verhef is tot bepaalde wetenskaplike studierigtings, is opvoedkundige en sielkundige beginsels al baie goed toegepas. Nuwere navorsing op hierdie gebiede leer ons die kind beter verstaan en help i.v.m. metode, ouderdoms- en geslagsgroepering ens. Terwyl ek in die opvoedkundige hulpverlening by die kategese nie iets negatiefs opgemerk het nie, voel ek tog dat die Kerk t.o.v. veral die sielkunde versigtig moet wees. Die sielkunde het 'n neiging om die misterie van die werking van die Heilige Gees te ignoreer en om die grootste wonders van wedergeboorte en bekering en geloof in die mens te probeer verklaar bloot volgens sielkundige insig. ${ }^{\circ}$ Dit is genoeg as die waarskuwing uitgespreek word dat die kategete op hulle hoede moet wees vir die hulpwetenskappe wat hulle gebruik.

Metode sal al meer en meer rekening moet hou met massamedia. 'n Goeie voorbeeld van hoe dit gebruik kan word is bv. die reeks artikels wat gedurende 1974 in „Die Transvaler" gepubliseer is en van Bybelkor uitgegaan het. Indien sodanige samewerking verkry kan word en die kleed van 'n koerant waarin hierdie kategese aangebied word nie andersins te erg besoedel is nie, kan groot waarde hieruit geput word. Die S.A.U.K. bied in sy Sondagprogramme ook uiters waardevolle diens. Byna al die kerke is reeds besig om te besin oor die gebruik van televisie vir bediening van die Woord van God. Dit bied besondere moontlikhede vir kategese. ${ }^{70}$

Die liturgie word van Rooms-Katolieke kant baie sterk beklemtoon as 'n middel tot kategese. Dit word ook gestel dat kategese juis moet opvoed tot die regte liturgie want daarin lê die regte ontmoeting met God opgesluit. ${ }^{71}$ Hier het ons m.i. nie 'n volledige prent nie, want liturgie en erediens bied wel die situasie van ontmoeting 
tussen God en sy volk, maar kategese moet tog eintlik 'n ander mikpunt hê, nl. dat uiteindelik alles erediens sal wees. Die mikpunt moet hier niks anders wees as die volkome koninkryk van God nie. „Wees julle dan volmaak soos julle Vader in die hemele volmaak is" (Matt. 5:48). Kategese moet dus nie net bring tot die regte ontmoeting in die erediens nie, maar wel tot getuienis vir Jesus Christus in die volle lewe.

Dis belangrik dat die metode van die Heidelbergse Kategismus vandag ook van Rooms-Katolieke kant gelyk gegee word en dat die motivering juis is dat die liefde van God dan beter spreek. ${ }^{n}$ Dit gaan hier oor die plek waar die wet in 'n sistematies opgeboude kategismus moet kom. Pierce sê dat so ook die boodskap van die Bybel beter oorgedra word. Die orde van Apostoliese geloofsbelydenis, sakramente en dan die wet word nou aanvaar terwyl dit tevore menigmaal in die volgorde van belydenis, wet, sakramente gegee is.

Wat die metode van kategese die meeste raak in die jongste tyd is alles wat gesê en geskryf word oor aanpassing by die inheemse kultuur. Hieroor word in Afrika soveel gesê en beplan dat 'n mens dit sonder twyfel kan bestempel as die saak wat die belangrikste beskou word t.o.v. metode. Sonder om te oortree op die terrein van ander referente wil ek graag die volgende opmerkings hieroor maak.

By die aaansluiting wat voorgestaan word, blyk die kloof tussen die Rooms-Katolieke en die tradisionele Protestantse hoofrigtings die duidelikste. Met opset sê ek die tradisionele Protestantse rigtings omdat in die moderne teologie van Protestantse kant daar sekere sake kom wat ten nouste aansluit by die Rooms-Katolieke teologie. Dit gaan hier veral oor die natuurlike Godskennis. Rooms-Katolieke teoloë stel dit onomwonde dat Afrika God geken het en gedien het deur hulle natuurlike Godskennis voordat die Evangelie van Jesus Christus aan hulle verkondig is. ${ }^{73}$ Die kategese moet nou net hierby aansluit en die Godsbeeld korrigeer. Die Protestantse teologie wat openbaring van God in die geskiedenis en natuur vandag as van meer waarde ag as die Bybel, moet noodwendig tot dieselfde gevolgtrekking kom, veral as soos by die geval van die Rooms-Katolieke Kerk die belangrikheid van Rom. 1:18 dat die mense moedswillig die waarheid in ongeregtigheid onderdruk, nie in sy volle betekenis gehandhaaf word nie. Hierdie rigting gaan sover om dit te stel dat daar eers ' $n$ bekering tot God is en dan tot Christus. ${ }^{74}$ Hierdie tipe aanpassing bring sinkretisme van die ergste graad mee, waar uiteindelik die vraag moet opkom of die Afrika-mens nou God dien of die godsbeeld wat hy tevore gehad het, 'n godsbeeld wat net effe verander is deur wat hy van die Christelike kerk gekry het.

Aanpassing in die metode gaan ook te ver wanneer 'n dekulturisering van die Bybelse stof in so 'n mate voorgestaan word dat wat God met die Jode gedoen het voorgestel word asof dit met die mense van Afrika gedoen is. ${ }^{75}$ Hierteenoor kan gerus genoem word die ander uiterste wat van die kant van die Wêreldraad van Kerke kom, nl. dat daar kultuurverandering moet wees om sodoende gelykheid onder mense te bewerk en botsings uit te skakel. ${ }^{76}$

Aanpassing deur dramatisering, deur inheemse musiek, sang 
en liefde vir ritme te gebruik, inheemse spreuke wat waarhede vertolk in te sluit en ander metodes om aan te sluit, word algemeen voorgestaan. Wanneer Seumois en Mangematin waarsku teen veruit. wendiging van die Bybel wanneer allerhande versieringkies aangeplak word by Bybelverhale, ${ }^{\pi}$ geld die waarskuwing in hoër mate van dramatisering. 'n Mens kan nie wegkom van die intuïtiewe aanvoeling dat by die dramatisering waarvoor die Afrika-kinders so lief is, dit meer dikwels gedoen word vir die genot van die spel as dat daar werklik deurgedring word tot die oordra van kennis of 'n boodskap wat die verhouding met God beinnvloed en laat beleef nie. Laat ons net een voorbeeld uit die werklike lewe neem: In die Gereformeerde Kerk in Vendaland het jongmense onlangs in 'n program wat hulleself aangebied het die laaste oordeel gedramatiseer. Een „,met 'n groot stem" het in die hoek van 'n vertrek op 'n effense verhoog gaan staan. Voor hom het 'n lang ry aangekom en hy het hulle na links of regs uitgewys met die verklaring dat die een veroordeel en die ander gered is. Hy self het natuurlik die rol van God gespeel.

Die jag na aanpassing by Afrika kan ons ernstige foute laat begaan. In ons poging om die klein diamantjie van regte aanpassing by die inheemse kultuur wat nog ontbreek in die kroon te verkry, moet ons nie die hele kroon van ons metode veral met die grootste diamant daarin, vertelling, verloor nie. Daar is 'n rykdom van hulpmiddele wat ook aanpas by die swartmense van Afrika wat gebruik kan word, maar die aandag moet nie so gefikseer wees op die kultureel-eie van Afrika dat ons vergeet dat blote vertelling wat die beste metode is vir kategese, universeel is en ook die belangrikste metode vir Afrika in sy bestaan voor kontak met die Blanke was nie. In al ons pogings om metodes te vind wat beter aanpas word ons aandag so afgetrek dat ons hierdie beste van alle middele nie wetenskaplik genoeg gebruik nie. Verder, as Paulus sê dat hy Jesus Christus asof voor die oë van die Galasiërs gekruisig gebring het, dan verwys hy na wat hy met die mondelinge prediking gedoen het (Gal. $3: 1)$. As Jesus die gelykenisse vertel, dan is dit woordskilderinge waarmee Hy Hom tot die skare rig. Ek is buitendien oortuig dat die Blankes hulle kragte eerder moet toespits op goedopgeleide swart teoloë sodat húlle die regte rigting in die kulturele aanpassing sal aandui as dat ons self dit sal probeer doen. Dit is nie so maklik om in die vel van die swartman in te kruip nie. Vandaar dat 'n mens somtyds merk dat Blankes veral by die toenemende geleerdheid die swartman eintlik beledig deur nog altyd met kinderagtige metodes na hom te kom.

Hierdie opmerkings is nie bedoel om die regte aanpassing by die kultuur te verkleineer nie. Inteendeel, dit is uiters belangrik. Alleen maar: Ons is nou op die kruin van hierdie begeerte om aan te pas en dit laat ons ietwat reaksionêr optree en die universele waardes uit die oog verloor. Wanneer gedink word aan aanpassing in die metode by Afrika moet 'n sorgvuldige balans tussen die universeel-ware en die partikulier-kulturele gehandhaaf word.

Dit is goed om te luister na die stem van 'n swartman wanneer 
hy bv. van die sang van die swartmense sê dat, singing in Black Churches is filled with soul but does not win souls".78 Hy toon aan dat hierdie sang eintlik, hoewel pragtig, 'n soort selfbedrog kan wees waarmee mense hulleself tevrede stel. Dit is ook goed om ag te gee op die waarskuwing dat ons nie net moet ingestel wees op aanpassing by Afrika nie, maar ook op korreksie. ${ }^{79}$

\section{Vernuwing t.o.v. die inhoud}

Slegs enkele gedagtes hieroor. Algemeen word die Bybel nog weer as die belangrikste boek by kategese beskou. Ledogar roep tot terugkeer na die Bybel as hy sê dat al die pogings om die Christelike godsdiens werklik in die harte te laat ingaan nog buite die Bybel om was en dat daar nou na die antwoord van die Bybel gevra moet word..$^{80}$

Hersiening van bestaande leerboeke word oor die algemeen as belangrik beskou. Kategismusse wat vir eeue gebruik is, word weer in oënskou geneem om te sien of hulle nog beantwoord in die omstandighede van die mense van vandag en die volke waar die Kerk nou gekom het. Eenvormigheid en gradering van boeke geniet aandag en pragtige nuwe werke het al verskyn.

1 Botha, P. B.: The congregation and catechetical training. (Ongepubliseerd), p. 10, vgl. ook p. 9 en 13. (Referaat op die Seminar for theology study group, June 1971 oor die tema Building a healthy congregation.)

2 Luzbetak, L. J.: Christo-paganism. Practical anthropology, vol. 13, 1966, p. $3: 115-121$ en $3: 128$.

3 Wevitavidanelage, S.: Impulsen voor de catechese in missiegebieden. Concilium: Internationaal tijdschrift voor theologie, Jrg. 6, no. 3, Maart 1970, p. 77.

4 Colomb, J.: Een actueel terrein van de catechese in het geheel van de kerk. Concilium, Jrg. 6, no. 3, Maart 1970, p. 18.

5 Wirt, S. E.: Ask the Maoris. Decision, Vol. 15, no. 12, 1974, p. 2.

6 Botha, op. cit., p. 9.

Buehlmann, W.: Catechetical renewal in Africa. In Katigondo: Presenting the Christian message to Africa, ed. by R. J. Ledogar, London, Geoffrey Chapman, 1965, p. 1, 2.

7 Weber, H. R.: The communication of the Gospel to illiterates. London, SCM press, 1957 (I.M.C. research pamphlet no. 4), p. 14.

8 Ibid.

9 Hearne, B.: The future of adult catechesis. African ecclesiastical review (AFER), Vol. VI, no. 1 en 2, 1974, p. 164. Soortgelyke gedagtes word ook deur Botha en Gerdener uitgespreek. Vgl. Botha, op. cit., p. 8.

10 Echarren, R: Geloofsoverdracht gezien vanuit de gegeven hedendaagse sociale structuren. Concilium, Jrg. 6, no. 3, 1970, p. 8.

11 Botha, op. cit., p. 2.

12 Burden, J.: Soeklig op die kategese in die N.G. Kerk in Afrika. Nederduitse Gereformeerde Teologiese Tydskrif (NGTT), Vol. XIV, no. 1, 1973, p. 65 . 
13 Vgl. slegs Kilian, I. H. R.: Die kategetiese onderrig in die Ned. Geref. Kerk in Afrika met besondere verwysing na die plattelandse Bantoe van Transvaal; Skripsie ingelewer vir die graad M.Th., Stellenbosch, Okt. 1972 (ongepubliseerd), p. 6-7.

14 Botha, op. cit., p. 10.

15 Pierce, A.: Catechetics in evolution. AFER, Vol. XV, no. 2, 1973, p. 134.

16 Vgl. slegs Echarren, op. cit., p. 17; Willekens, W. F.: Religious formation of adult Christians. In Katigondo, p. 77; Ledogar, R.: Introduction. In Katigondo, p. xiii. Wevitavidanelage, op. cit., p. 76; Lehman, K.: Ten geleide. Concilium, Vol. 6, no. 3, 1970, p. 5; Botha, op. cit., p. 8-10; Bijlsma, R.: Kleine catechetiek. Nijkerk, G. F.; Callenbach N. V., 1962, p. 13, 91.

17 Buehlmann, op. cit., p. 12.

Wevitavidanelage, op. cit., p. 80.

18 Pierce, op. cit., p. 134.

$1 \theta$ Malan, D. J.: 'n Nuwe bedeling in ons kategetiese arbeid. Vgl. ook Louw, D. J.: 'n Woord vooraf. In 'n Nuwe bedeling in ons kategetiese arbeid, p. 3.

20 Kilian, op. cit., p. 2.

21 Wevitavidanelage, op. cit., p. 80.

22 Ibid., p. 76.

23 Prins, J. M. G.: Die Heidelbergse kategismus as kategetlese leerstof. Proefskrif vir D.Th., Stellenbosch, 1973 (ongepubliseerd), p. 241.

24 Bournique, J. M.: Note on pre evangelization. In Katigondo, p. 64.

25 Prins, op. cit., p. 241.

26 Pierce, op. cit., p. 140. Vgl. ook p. 138 waar hy vra waar God Hom vandag openbaar, en sy verduideliking dat die "Life theme"-metode die openbaring verstaan as ,a present personal happening between Christ and ourselves, between Christ and our fellowmen. Revelation means God giving himself, here and now, in an historical, continuing intercommunion with us. Our response is part of the revelation. Revelation means a personal dynamic awareness of God's personal self communication to us now", p. 141.

27 Wereldraad van Kerke: The church for others; two reports on the missionary structure of the congregation. Geneva, WCC, 1968, p. 78.

Bucher, H.: Youth work in South Africa: a challenge for the church. Schöneck-Beckenried, Nouvelle Revue de science missionaire, 1973, p. 181.

29 Vgl. Kruger, M. A.: Vryheid vir die ganse mensheid? Die vryheidsgedagte in die ekumeniese sendingdiskussies. Proefskrif vir Th.D. Potchefstroom, 1973 (ongepubliseerd), p. 214-220, veral p. 219.

30 Wevitavidanelage, op. cit., p. 79.

31 Kittel, G.: Theological dictionary of the New Testament. Grand Rapids, Wm. B. Eerdmans, 1965, Vol. III, p. 638-640.

32 Biesterveld, P.: Het karakter der catechese, Kampen, J. H. Kok, 1900, p. 68.

33 Kilian, op. cit., p. 19. Prins, op. cit., p. 57.

34 Biesterveld, op. cit., p. 79. Moll, E.: Katechetiek of theorie van het godsdienstig onderwijs. Tiel, 1856, p. 54.

35 De Villiers, D. W.: Die kategese in die N.G. Kerk in S.A. Proefskrif vir D.Th. Stellenbosch, Potcheistroom, Pro Rege-Pers Bpk., 1957, p. 26.

36 Kilian, op. cit., p. 22.

37 Vgl. bv. die doel volgens Hirmer, O.: The first approach to adult cate- 
chumens. In Katigondo, p. 56-57.

54 Colomb, op. cit., p. 21.

55 Willekens, op. cit., p. 80.

56 Bijlsma, op. cit., p. 258.

57 Willekens, op. cit., p. 78 en Wevitavidanelage, op. cit., j. 81.

58 Vgl. Burden, op. cit., p. 55; Van der Merwe, D. C. S.: Verbond en Sending, Potchefstroom 1965, Proefskrif Potchefstroom (ongepubliseerd), p. 295-296 en 299; Pauw, C. M.: Die bearbe iding van die jeug binne die N.G. Bantoekerk in die Transkei, M.Th. skripsie. Stellenbosch, 1968, p. 7.

59 Hirmer, op. cit., p. 62.

60 Vgl. slegs Deut. $6: 7$.

61 Buehlmann, op. cit., p. 9.

62 Ibid., p. 81.

63 Vgl. Willekens, op. cit., p. 76; Buehlmann, op. cit., p. 9; Botha, op. cit., p. 11, 16; Kamfer, P. P. A.: Kategese en praktyk (referaat gelewer tydens Raadsitting te Decoligny op 12 April 1973). Ongepubliseerd, p. 4.

Botha, op. cit., p. 3.

Ibid., p. 13; Wevitavidanelage, op. cit., p. 76.

Burden, op. cit., p. 51.

Buehlmann, op. cit., p. 7.

Vgl. Pierce, op. cit., p. 135-141 vir hierdie metodes.

Vgl. Gouws, A. G. S.: Die jeugdige op weg van st. V na st. X. In Onderrig uit die Woord. Bloemfontein, Sondagskool Boekhandel, 1874, p. 28 waar hy van die sorg van mense vir hulle kinders en opvoedingsituasies praat en dan se: „En wat is dit anders as versorgingsmiddele en opvoedingsituasies wat aan hom vertroue, en uiteindelik, wanneer dit op God gerig word, ook geloof gee?" Gouws sluit ook aan by Erikson en meen dat begrip van die kind en beplanning vir sy onderrig kan uitgaan van 'n goeie beg:n (dus nie vermelding van erfsonde nie) maar met inagneming van die "normale" ontwikkelingsgang en die "ongelukke" wat op die pad van die kind kom. P. 23-24.

70 Vgl. Willekens, op. cit., p. 80; Kilian, op. cit., p. 2.

71 Luykx, B.: Catechetical value of the liturgy. In Katigondo, p. 41-44. 
72 Pierce, op. cit., p. 136.

73 Luykx, op. cit., p. 45; Hirmer, op. cit., p. 58; Buehlmann, op. cit., p. 6; Seumo:s, X. en Mangematin, B.: Adapting modern catechesis to Africa today. In Katigondo, p. 15, 26.

74 Seumois en Mangematin, op. cit., p. 21.

75 Echarren, op. cit., p. 16.

76 Maris, J. C. e.a.: Kruistocht tegen Bijbelse zending. Bangkok en de Oecumenische Beweging. H:lversum, Evangelische Omroep, 1973, p. 11.

77 Seumois en Mangematin, op. cit., p. 34.

78 Hinkle, J. H.: Soul winning in black churches. Grand Rapids, Baker Book House, 1973, p. 55-61.

79 Seumois en Mangemat:n, op. cit., p. 35.

80 Ledogar, R.: Introduction. In Katigondo, p. vii. 